\title{
JURNALISME DATA : TRANSFORMASI DAN TANTANGAN ERA DIGITAL
}

\author{
Hartinah Sanusi \\ Jurusan Jurnalistik, Fakultas Dakwah dan Komunikasi \\ UIN Alauddin Makassar \\ Email: tinaapriliasanusi@gmail.com
}

\begin{abstract}
Journalism throughout the history of human civilization as the invention and technological development undergoes a transformation. The existing forms and varieties of journalism serve as a marker for every age. In today's digital age, the emergence of the explosive phenomenon of data and information gave rise to a new format for journalism known as data journalism. The presence of data journalism breaks down as well as raises a new framework of journalism. A form of journalism that adapts to principles in the era of free and open digital technology. This paper attempts to examine the study of journalism with the complexity of its change as an interesting study as well as challenging both conceptually and practically in Indonesia.
\end{abstract}

Keywords: Journalism, data journalism, internet and digital technology, bigdata.

\section{PENDAHULUAN}

\section{A. Latar Belakang}

Pesatnya perkembangan informasi dan berita digital (online) berimplikasi pada perubahan format atau bentuk jurnalisme saat ini. Dulu aktivitas jurnalisme hanya mengandalkan pengumpulan data dan informasi melalui wawancara dengan narasumber atau terjun langsung ke lokasi liputan. Kini, dengan ketersediaan data dan informasi yang begitu melimpah serta akses yang sangat cepat memunculkan hal baru dalam dunia jurnalisme. Informasi kini bisa diperoleh melalui proses pengumpulan data di internet, diolah dan dianalisis, kemudian disajikan dengan tampilan visual data yang menarik dan interaktif. Sebuah bentuk baru jurnalisme yang dikenal dengan jurnalisme data atau sebagian kalangan menyebutnya datadriven journalism.

Jurnalisme data merupakan kombinasi dari aktivitas menghimpun dan memvalidasi data sebagai sumber informasi yang utama, 'menginterogasi' data dengan menggunakan aplikasi olah data statistik, dan visualisasi data ${ }^{1}$. Bagi 
kebanyakan orang, data-data yang dirilis dalam situs-situs resmi pemerintah atau perusahaan swasta selama bertahun-tahun mungkin hanya sekedar data biasa saja. Namun, data yang sedemikian banyak justru menjadi 'tambang data' berupa bahan mentah bagi jurnalis data. Para jurnalis data-lah yang mengolah, menganalisis dan menginterpretasi untuk menghasilkan sejumlah laporan berita.

Jurnalisme data memberikan banyak peluang sekaligus tantangan bagi jurnalis baik dalam pencarian data, melakukan investigasi dan mengembangkan teknik analisis data, menginterpretasi data hingga menyajikannya dengan visual data yang lebih kreatif dan interaktif. Tidak hanya itu, jurnalisme data juga mendorong pada praktik-praktik jurnalisme yang lebih terbuka, berkualitas dan transparans. Survey google news-lab pada 2017 lalu juga menunjukkan jurnalisme data mampu berperan dalam mengubah norma-norma di masyarakat, mengubah kepercayaan terhadap media, dan menjadi solusi bagi masalah fake news ${ }^{2}$. Karakter teknologi internet yang hipertekstual, multimedia dan interaktif memberi kemudahan bagi khalayak mengetahui sumber-sumber data (link) yang digunakan oleh jurnalis. Hal ini, berdampak pada kredibilitas dan akuntabilitas organisasi berita sebagai penyedia informasi bagi masyarakat.

Era digital menuntut tambahan keahlian baru dalam bidang jurnalisme. Para jurnalis dituntut memiliki kemampuan terutama dalam menggunakan aplikasiaplikasi atau tools tertentu dalam menghimpun data dan menemukan fakta-fakta menarik untuk diolah dan dianalisis. Di negara-negara dengan akses teknologi informasi digital (internet) yang demikian luas dan terbuka seperti di Inggris atau Amerika Serikat, jurnalisme data sebenarnya bukanlah sesuatu yang sama sekali baru. Lebih dari satu dekade lalu media-media besar seperti The Guardian dan Times New York telah mengawali model jurnalisme data ${ }^{3}$. Ke dua media ini juga menyediakan kanal khusus untuk laporan jurnalisme data, yakni datablog pada situs online www.theguardian.com dan laman the upshot pada situs www.nytimes.com. Jurnalisme data kini merupakan hal yang begitu canggih (sophisticated), sebuah bentuk inovasi dalam praktik jurnalisme di era digital.

Dalam lingkungan akademisi, jurnalisme data juga menjadi salah satu topik kajian penting di kalangan peneliti media. Pesatnya perkembangan jurnalisme 
data diikuti dengan meningkatnya jumlah penelitian. Ausserhofer dkk melakukan studi literatur terhadap penelitian jurnalisme data yang terpublikasi di jurnal-jurnal internasional dan menemukan 772 publikasi penelitian di 15 database jurnal internasional dalam kurun waktu 20 tahun terakhir ${ }^{4}$. Sementara, di Indonesia meski sejumlah media berita online sudah ada yang mengadopsi model jurnalisme ini, namun publikasi penelitian terkait jurnalisme data masih belum banyak ditemukan. Tulisan ini mencoba mengkaji lebih jauh konsep dan praktik jurnalisme data sebagai pijakan dasar bagi penulisan selanjutnya. Lebih jauh, penulis juga mencoba mengurai tantangan bagi perkembangan praktik jurnalisme data di Indonesia.

\section{B. Rumusan Masalah}

Berdasarkan latar belakang masalah yang sudah diuraikan, penulis merumuskan tiga pokok masalah yang akan menjadi pembahasan dalam tulisan ini, sebagai berikut :

1. Bagaimana latar belakang yang mendasari keberadaan jurnalisme data?

2. Bagaimana konsep dan ruang lingkup serta karakteristik jurnalisme data?

3. Bagaimana perkembangan dan tantangan jurnalisme data di Indonesia?

\section{PEMBAHASAN}

\section{A. Transformasi Jurnalisme dan Fenomena Big Data : Awal Mula Jurnalisme Data}

Jurnalisme sejak awal kemunculannya telah menjadi perhatian penting sebagai salah satu bidang kajian dalam ilmu komunikasi. Salah satu fokus kajian studi jurnalisme yang menarik perhatian kalangan peneliti dan akademisi belakangan ini adalah pada perubahan-perubahan atau transformasi yang terjadi dalam jurnalisme sebagai efek dari perkembangan teknologi komunikasi dan informasi.

Jurnalisme sebagai sebuah sistem yang menyediakan informasi bagi masyarakat sebagaimana dikemukakan Kovach dan Rosenstiel, memang kuat dipengaruhi oleh teknologi. Produksi dan distribusi informasi oleh media 
mengalami perubahan yang signifikan terkait teknologi, termasuk juga bagaimana khalayak mengakses informasi di media yang ada. Sejak era teknologi mesin cetak hingga penemuan radio dan televisi, jurnalisme mengalami transformasi, dari jurnalisme cetak ke jurnalisme penyiaran (broadcasting), hingga jurnalisme online. Pengaruh teknologi ini tidak hanya pada praktik jurnalisme saja melainkan juga studi dan penelitian jurnalisme, seperti ditekankan Deuze dan Witschge :

Under conditions of technology and the market, the practice of journalism is (and always has been) often something quite different than its biased selfpresentation and the way dominant conceptualizations of the field get articulated in journalism education and research ${ }^{5}$.

Kini, di era digital dengan kekuatan teknologi berbasis internet, informasi dan data disajikan dan diakses dengan cara dan bentuk yang sama sekali baru. Internet memungkinkan khalayak mengakses informasi dan data dengan semua bentuk media yang telah ada (baca:media tradisional). Biagi melihat internet sebagai kombinasi dari ribuan jaringan komputer yang mengirim dan menerima data dari seluruh dunia, memunculkan teknologi yang menggabungkan semua bentuk teks, gambar, suara dan video dalam satu sajian informasi.

Biagi lebih jauh menjelaskan teknologi internet juga menciptakan bahasa dan mekanisme yang memungkinkan manusia saling berbagi semua jenis informasi secara elektronik (digital information) dengan penemuan World Wide Web atau lebih dikenal dengan istilah website atau situs. Dengan bantuan browser dan search engine (mesin pencari) memudahkan untuk mengakses halaman web dan mencari informasi yang dibutuhkan dalam basis data komputer. Melalui web inilah ledakan informasi dan data (big data) terjadi dalam hitungan menit bahkan detik setiap harinya. Sebuah kumpulan informasi dan data yang luar biasa besar dan terus bertambah dengan cepat, dengan jenis format data yang juga sangat beragam baik terstuktur ataupun tidak.

Konsep big data pada dasarnya merujuk pada ketersediaan set data dalam jumlah yang sangat besar sehingga tidak memungkinkan dikelola tanpa menggunakan teknologi aplikasi tertentu. Suthaharan menggambarkan big data 
sebagai sekumpulan data dengan ciri utama pada volume, ragam dan kecepatan yang membutuhkan teknologi khusus untuk mengakses dan mengolahnya.

Big Data is currently defined using three data characteristics: volume, variety and velocity. It means that some point in time, when the volume, variety and velocity of the data are increased, the current techniques and technologies may not be able to handle storage and processing of the data ${ }^{6}$.

Adapun, Aziz melihat big data ini tidak lain adalah sebuah proses mediatisasi di bidang informasi yakni berupa ketersediaan data dalam jumlah yang besar sebagai hasil akumulasi produksi data internal maupun eksternal lembaga-lembaga yang ada. Dibutuhkan aplikasi teknologi khusus untuk mengakses, memanipulasi, menganalisis dan mempresentasikan data. Aziz juga secara khusus menyoroti pengaruh fenomena big data ini terhadap praktik jurnalisme.

Di dunia media, perkembangan big data juga berpengaruh dengan dikembangkannya varian baru jurnalistik yang bertumpu pada data. Praktik jurnalistik baru ini menggunakan data sebagai alat untuk melaporkan peristiwa yang terjadi di masyarakat, mengangkat isu-isu penting, dan upaya kontrol terhadap pemerintah yang sedang berkuasa ${ }^{7}$.

Lebih jauh, penelitian Lewis dan Westlung terkait fenomena big data dan jurnalisme menunjukkan adanya upaya jurnalis dan organisasi berita untuk memahami, melakukan suatu tindakan dan menghasilkan hal yang bernilai dari big data. Secara keseluruhan, perkembangan big data memiliki potensi besar untuk memahami aspek-aspek lain dari jurnalisme baik itu aspek epistemologi, keahlian (expertise), ekonomi dan etika.

Fenomena big data dan keterbukaan data (open data) di era informasi digital telah menjadi satu perhatian khusus dalam studi jurnalisme yang dikenal dengan jurnalisme data. Meski, terdapat perdebatan apakah jurnalisme dan perubahannya saat ini disebabkan oleh pengaruh teknologi digital atau hal lainnya, namun fenomena big data ini diakui makin menekankan perubahan dalam studi dan praktik jurnalisme ${ }^{8}$. Big data ibarat 'gunung' tambang data bagi organisasi media. Jurnalis hanya perlu menguasai cara yang efektif dan efisien mengolah tambang data tersebut untuk menemukan informasi yang penting dan dibutuhkan khalayak. 
Saat ini, data dan informasi dengan mudah dan cepat bisa diperoleh melalui situs-situs pencarian data di internet. Sebagai catatan, di tahun 2017 mesin pencari data, google memproses lebih dari 3 triliun data per hari dan lebih dari 195.000 set data tersedia di data.gov ${ }^{9}$. Hal ini, menunjukkan besarnya kebutuhan masyarakat akan data dan informasi di era digital dan tentu saja jurnalisme berperan penting didalamnya. Jurnalisme data tidak hanya sekedar menyajikan angka-angka saja, tetapi membantu khalayak memahami makna angka-angka tersebut untuk seterusnya menjadi referensi bagi khalayak dalam banyak hal, misalnya dalam memengaruhi opini atau pengambilan keputusan.

Sebuah media berita online di Amerika, Las Vegas Sun melakukan penelusuran data dan fakta terkait pelayanan rumah sakit di Las Vegas pada tahun 2010. Laporan berjudul "Do No Harm : Hospital Care in Las Vegas, A breakthrough in medical transparency" menelaah lebih dari 2,9 juta data billing rumah sakit Nevada dan melakukan wawancara dengan 150 pasien. Dari data tersebut, Las Vegas Sun mengungkap fakta mencengangkan tentang kesalahan tindakan di rumah sakit. Ada lebih dari 300 kasus dimana pasien meninggal akibat kesalahan tindakan yang sebenarnya bisa dicegah. Hal menarik dari laporan ini, data yang disajikan bukan hanya hasil analisis jurnalis saja, melainkan juga semua data mentah dan dokumen resmi yang dihimpun jurnalis pun bisa diakses oleh khalayak ${ }^{10}$. Laporan ini tentu saja membantu khalayak untuk lebih berhati-hati sekaligus juga sebagai kritik tajam untuk tindakan evaluasi pada sistem pelayanan medis di semua rumah sakit.

Jurnalisme pada dasarnya tidak lain adalah sebuah aktifitas menghimpun data. Bounegru menyoroti hal ini di dalam bukunya The Data Journalism Handbook bahwa selama berabad-abad para jurnalis telah menggunakan data sebagai sumber informasi untuk membuat berita. Rogers bahkan menyebutkan contoh pertama jurnalisme data telah dimulai sejak 1821 dalam laporan edisi pertama surat kabar The Guardian yang menyajikan tabel data tentang pendaftaran dan biaya siswa di sekolah Manchester. Menurut Rogers, letak perbedaannya hanya pada sumber data yang digunakan, saat ini jurnalis lebih banyak menggunakan data dari komputer (internet). 
Istilah jurnalisme data pertama kali digunakan oleh seorang pengembang perangkat lunak (software developer) di surat kabar Washington Post, Adrian Holovaty yang mengungkap bagaimana data diatur dan diorganisasikan oleh media. Holovaty juga pernah menulis sebuah artikel di 2006 tentang bagaimana seharusnya situs-situs surat kabar perlu diubah ${ }^{11}$.

Sekitar 2009, The Guardian telah meluncurkan kanal Datablog dalam situs online-nya. Jurnalis The Guardian memvisualisasikan pengeluaran para menteri di parlemen Inggris dan meluncurkan informasi ke publik tentang pengeluaran mereka di parlemen hingga saat ini. Pada bulan Juli 2010, The Guardian mulai menerbitkan jurnalisme data berdasarkan war $\log s$, sebuah pengungkapan besarbesaran ribuan catatan perang Afghanistan yang diterbitkan oleh Wikileaks. Howard menyoroti bagaimana situs wikileaks telah ikut mengubah bentuk jurnalisme dengan memberikan ruang bagi organisasi media (ruang berita) untuk mengadopsi model pelaporan dengan data-data tersebut.

Selanjutnya, penggunaan istilah jurnalisme data mulai meluas dan menjadi wacana utama pada 2014 dengan bermunculannya media-media berita online yang mengusung format jurnalisme data. Seperti FiveThirtyEight.com dan Vox.com, ProPublica.com, Appp3d.com dari The Mirror, QZ.com dari Atlantic Media Group, The Economist's DataBlog, The Guardian Datablog, The Upshot dari New York Times, Graphic dari Washington Post dan Die Zeit di Berlin.

Ruang lingkup jurnalisme yang digerakkan oleh data pun semakin berkembang dan menuntut kemampuan atau skill teknologi aplikasi olah data statistik mulai dari yang sederhana hingga yang kompleks. Sebuah studi dilakukan Boyles dan Meyer dengan mewawancarai 18 jurnalis pemimpin redaksi surat kabar di Amerika Serikat terkait tren jurnalisme data. Hasilnya cukup menarik bahwa jurnalisme data diprediksi akan menjadi sebuah rutinitas media, bukan lagi bidang khusus jurnalisme seiring dengan makin tingginya tuntutan akan skill mengolah dan menganalisis data bagi jurnalis. Lebih jauh, tampaknya organisasi berita menunjukkan usaha yang konsisten terhadap aktivitas jurnalisme data dengan melakukan perubahan struktur organisasi demi mengakomodir kemampuan jurnalis di bidang ini. 
At the moment, however, data practitioners are seen as technical experts within the newsroom - individuals whose work needs are uniquely managed. As newsrooms continue to experiment with data journalism, organizational structures will concurrently shift to accommodate the talents of new, specialized practitioner ${ }^{12}$.

Organisasi berita di luar telah mendorong para jurnalis untuk lebih meningkatkan pengalaman bekerja dengan data-data yang lebih kompleks. Meski demikian, penulis belum melihat sejauh mana organisasi berita mampu menciptakan budaya jurnalisme data di lingkungan jurnalis. Sehingga jurnalisme data bukan lagi sekedar sebagai bentuk adaptasi dan inovasi terhadap perubahan teknologi media sekaligus menjadi daya tarik dan tantangan dalam industri media baik cetak, penyiaran televisi (broadcast data journalism) terlebih media online, namun ke depannya justru menjadi budaya jurnalisme data.

\section{B. Membangun Konsep Jurnalisme Data}

Sebagaimana dijelaskan di awal, fenomena big data telah banyak menarik perhatian berbagai kalangan terutama para praktisi dan akademisi bidang jurnalisme terkait dampak perubahan yang diakibatkan. Kehadiran jurnalisme data baik dalam konteks istilah (terminology) maupun definisi konsep juga mengalami perdebatan. Ada banyak istilah, definisi dan cara memahami jurnalisme data yang saling tumpang tindih, sulit mencapai satu definisi yang mencakup semuanya.

Istilah jurnalisme data seringkali tumpang tindih dengan sejumlah istilah lain yang lebih dulu muncul. Seperti jurnalisme berbasis data (data-driven journalism), laporan berbasis komputer atau disingkat CAR (Computer AssistedReporting), jurnalisme presisi (precision journalism), jurnalisme komputasi (computation journalism), jurnalisme pemrograman (programing journalism), dan jurnalisme algoritmik (algorithmic journalism). Tumpang tindih istilah ini berimplikasi pada sulitnya mendapatkan satu ontologi yang umum terkait konsep jurnalisme data ${ }^{12}$. Beragam istilah dan definisi yang muncul secara umum mengacu pada perubahan proses produksi berita, penekanan pada peran data sebagai sumber tambahan dalam proses pengumpulan informasi yang membutuhkan skill khusus, dan proses produksi berita berdasarkan analisis data 
yang mencakup sejumlah model visualisasi interaktif misalnya peta atau diagram $^{13}$. Namun demikian, masing-masing istilah tetap saja menggunakan data sebagai acuan utama, perbedaan umumnya disebabkan pendekatan metode jurnalisme yang saja.

Jurnalisme data umumnya didefinisikan sebagai jurnalisme yang berbasis pada sekumpulan besar data (big data). Bradshaw menjelaskan jurnalisme data tidak lain adalah hal-hal mendekati data atau sebuah aktivitas kompilasi data. Data menjadi sumber dalam jurnalisme data atau juga sebagai alat yang bisa digunakan dalam membuat berita, atau sekaligus kedua-duanya yakni sebagai sumber dan alat ${ }^{14}$. Schulsze dalam tesisnya menyebutkan kalangan akademisi mendefinisikan jurnalisme data sebagai kegiatan pengumpulan, analisis dan penyiapan informasi digital untuk tujuan publikasi jurnalistik. Lebih jauh, ia menyimpulkan jurnalisme data tidak lain adalah bentuk khusus dari laporan investigasi yang menggunakan data sebagai sumber informasi dan aplikasi data statistik untuk mengembangkan laporan dan disajikan dengan visual.

Data journalism represents a special form of investigation that uses data to develop stories. Moreover, it is a specialized way to treat data as an information source and interrogatethe researched material based on statistics. In the following, the findings are presented in a visual, sometimes graphical or in an interactive way to engage the audience ${ }^{15}$.

Sementara itu, Parasie dan Dagiral menyebutnya dengan istilah Computer Assisted-Reporting (CAR) atau programming journalism. Sejak 2013, CAR telah dikenal sebagai bagian dari disiplin ilmu jurnalisme yang penting. Elemen data dan program komputer tidak hanya sekedar bagian integral penting dari jurnalisme, melainkan bahan mentah sekaligus alat (tools) bagi visualisasi berita, kreativitas untuk khalayak dan juga berpotensi ekonomi (revenue) organisasi berita. Penelitian mereka terkait jurnalisme berbasis data dan kepentingan publik di kalangan jurnalis di Chicago US, menunjukkan adanya pengaruh yang signifikan antara metode kerja jurnalisme CAR terhadap kontribusi jurnalisme dengan kepentingan publik. Data diasumsikan dapat membantu jurnalis mengatur agenda politik melalui pengungkapan isu-isu publik ${ }^{16}$. 
Istilah lain yang merujuk pada jurnalisme data yakni jurnalisme presisi (precision journalism) yang dikenalkan oleh Philip Meyer :"..it means treating journalism as if it were a science, adopting a scientific method, scientific objectivity, and scientific ideals.. ${ }^{17}$. Jurnalisme presisi bertujuan untuk menyajikan laporan berita dengan topik-topik yang lebih ilmiah, yang mungkin sulit diakses. Menurut Meyer, dengan menggunakan dan mengadopsi metode penelitian sosial dalam mengumpulkan dan mengolah data melalui aplikasi program komputer dapat meningkatkan ketepatan, kedalaman dan akurasi berita.

Penggagas sekaligus editor kanal Datablog media online The Guardian, Simon Rogers, memberikan definisi yang lebih khusus dengan menekankan pada penyajian berita dengan beragam gaya visualisasi data, berupa narasi teks yang panjang ataupun angka-angka dalam grafik (infographis). Lebih jauh, Rogers menekankan pentingnya kemampuan menghimpun dan menyeleksi data, menganalisis dan menjadikan data sebagai hal yang sederhana dan mudah dipahami sekaligus juga penting bagi khalayak $^{18}$.

Terkait epistemologi jurnalisme data, berdasarkan kajian-kajian penelitian terdahulu Borges-Rey menggagas dua pendekatan yang bisa memberikan pemahaman lebih jauh, yaitu newshound paradigm dan teachie paradigm. Pendekatan newshound merujuk pada perspektif tradisi jurnalisme investigasi (investigative/muckraking journalism) yakni data merupakan komponen alat bukti dalam pemberitaan. Sementara, pendekatan teachie lebih mengacu pada logika komputasi, sebuah model jurnalisme kolaborasi antara profesi jurnalis, programer dan data analis. Lebih jauh, penelitian Borges-Rey di UK menunjukkan umumnya jurnalis data di London dalam menjalankan tugasnya bergerak antara dua pendekatan tersebut sesuai kebutuhan antara skill jurnalistik dan ilmu komputer.

Meski terdapat perbedaan penekanan dalam mendefinisikan jurnalisme data, penulis melihat adanya elemen-elemen umum yang menunjukkan kesamaan konsep yakni pada aktivitas jurnalistik yang memanfaatkan sejumlah besar data (kebanyakan data kuantitatif), analisis data dengan program komputer atau tools tertentu serta elemen visualisasi data yang lebih variatif dengan bantuan aplikasi penyajian data. 


\section{Perkembangan dan Tantangan Jurnalisme Data di Indonesia}

Perkembangan jurnalisme data di Indonesia memang belum sepesat di Amerika atau negara-negara di Eropa. Namun, praktik jurnalisme dengan pendekatan jurnalisme data telah dilakukan beberapa tahun belakangan. Penelitian yang dilakukan Badri, menunjukkan media online di Indonesia sudah mengadopsi inovasi jurnalisme data dengan memanfaatkan sumber terbuka dari himpunan data besar (big data) dan melakukan riset mandiri. Organisasi berita juga tampak memberikan dukungan bagi perkembangan jurnalisme data di Indonesia.

Jurnalisme data memang tergolong fenomena baru dalam dunia jurnalistik Indonesia. Berakar dari model jurnalisme investigasi, pada 2016 tim investigasi Tempo yang juga salah satu media rekanan ICIJ (The International Consortium for Investigative Journalist) memulai pendekatan jurnalisme data dalam kasus 'Berkas Panama' (Panama Papers). Sebuah kumpulan 11,5 juta dokumen rahasia yang dibuat oleh penyedia jasa perusahaan asal Panama, Mossack Fonseca. Dokumen berukuran 2,6 terabita ini diberikan oleh seorang sumber anonim kepada surat kabar di Jerman, Süddeutsche Zeitung pada Agustus 2015 dan International Consortium of Investigative Journalists (ICIJ). Dokumen bocoran ini kemudian disebarkan kepada dan dianalisis oleh kurang lebih 400 wartawan di 107 organisasi media di lebih dari 80 negara $^{19}$. Di Indonesia, tim investigasi Tempo merupakan satu-satunya rekanan organisasi media yang terlibat dalam pengungkapan kasus ini.

Dalam laporan investigasi 'Berkas Panama' (Panama Papers) di sejumlah edisi majalah tempo yang juga bisa diakses di https://investigasi.tempo.co, tim investigasi Tempo mengaitkan beberapa pengusaha dan politikus Indonesia dengan beberapa nama orang Indonesia yang terdaftar dalam dokumen tersebut. Hal ini, merupakan usaha Tempo memberikan konteks dan mengembangkan data temuannya, meski belum sepenuhnya dikategorikan sebagai produk jurnalisme data. 
Selain Tempo, penulis menelusuri ada sejumlah media lainnya di Indonesia yang sebenarnya juga telah banyak melakukan pendekatan jurnalisme data, apakah sekedar menyentuh kedalaman laporan ataupun melalui visual data yang interaktif. Media online dengan karakteristik hiperteks (hyperlink), multimedia dan keluasan 'ruang' penyajian berita sangat memungkinkan bagi berkembangnya model jurnalisme data. Misalnya, kompas.com sebagai salah satu media pionir yang hadir di dunia internet sejak 1995, telah banyak menghadirkan inovasi dalam mengembangkan jurnalisme di Indonesia. Selain menyajikan laporan-laporan dalam bentuk hard-news, soft-news/feature, dan laporan khusus lainnya dengan tuntutan up-date informasi yang tinggi, di 2008 kompas.com juga menyajikan laporan mendalam (Indepth Reporting) dalam bentuk visual yang menarik dan interaktif (multimedia story telling) dalam kanal Visual Interaktif Kompas $(\mathrm{VIK})^{20}$. Informasi disajikan dengan teknik penceritaan yang menarik dan mendalam, dilengkapi dengan tayangan video serta kaya dengan dokumentasi foto-foto jurnalistik. Pilihan tema berita dalam kanal VIK meski terbatas, namun memuaskan pembaca baik dari sisi kedalaman informasi maupun penyajian visual.

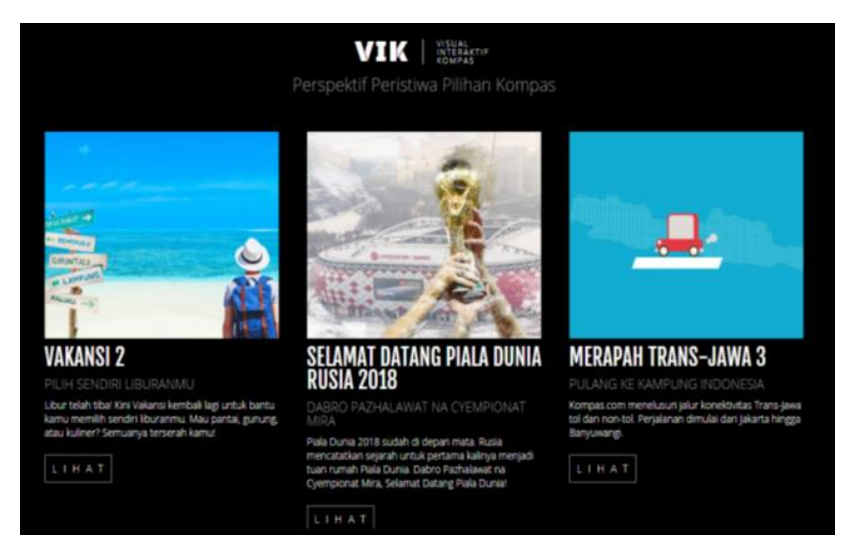


Media online lainnya yang juga mengacu pada jurnalisme data antara lain katadata.co.id, yakni organisasi media, data dan riset online dengan fokus pada laporan ekonomi dan bisnis. Sejak 2012, tim redaksi katadata.com mulai menyajikan berita, informasi, data, dan hasil riset secara mendalam bagi kepentingan para pemimpin bisnis dan pengambil kebijakan, namun dikemas secara lugas dan atraktif agar mudah dipahami publik. Berita dan informasi disajikan dalam bentuk teks, tampilan visual (infografik) yang memikat.

Katadata juga menyediakan kanal 'Databoks' yang menyajikan secara khusus informasi dan data berupa 'data statistik' dengan pilihan 'statistik terkini' atau 'statistik terpopuler', misalnya laporan terkait negara-negara dengan cadangan minyak terbesar disajikan dengan visual data menggunakan grafik batang $^{21}$. Selain itu, tersedia pilihan halaman 'dataset' yakni rilis data BPS dengan beragam pilihan industri yang dapat diunduh dalam format excel. Kanal data dan statistik ini ditujukan sebagai sarana efektif untuk mempublikasikan berbagai data dan informasi kepada

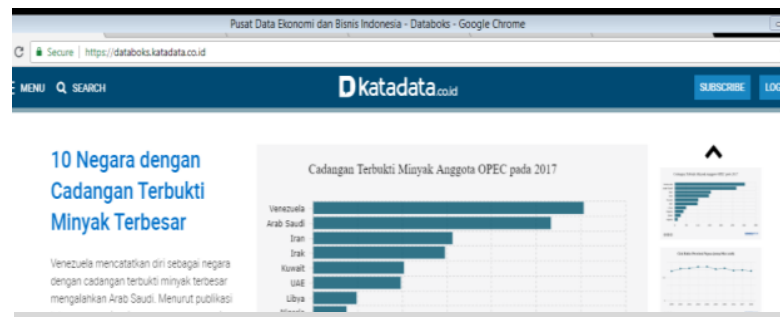
Gbr.2. Kanal Databoks di Situs www.katadata.co.id

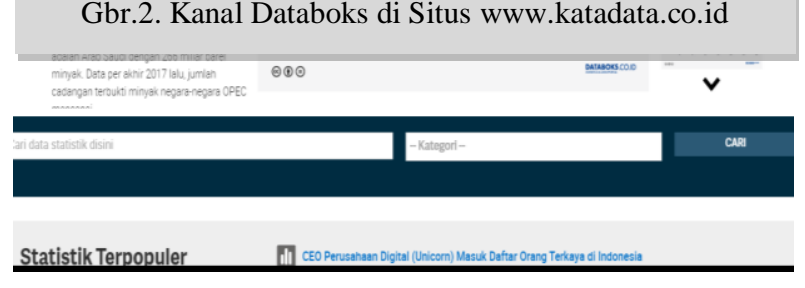
publik, serta menjadi sumber pencarian data yang dapat dimanfaatkan dengan mudah oleh para pengguna. Misalnya data pengeluaran per kapita disesuaikan menurut provinsi di Indonesia 2010-2017, data pertumbuhan industri mikro dari tahun ke tahun, dan lain sebagianya.

Selain kanal 'Databoks', redaksi katadata.co.id juga menyajikan informasi dan data yang menarik dalam kanal 'Infografik', 'Ekonografik' dan 'Infomark'.. Terkait aspek visualisasi data, penelitian Badri menunjukkan $70 \%$ pemberitaan katadata.co.id pada 01-31 Agustus 2017 menggunakan grafik batang dalam menyajikan data ${ }^{22}$. Penulis melihat hal ini terutama disebabkan kategori berita pada situs katadata.co.id memang lebih fokus pada laporan bisnis dan ekonomi yang banyak membutuhkan data berupa angka-angka. 
Di 2016, media online tirto.id yang mengusung format jurnalisme presisi mulai menyajikan laporan dengan memanfaatkan data berwujud foto, kutipan, rekaman peristiwa, serta data statistik yang ditampilkan baik secara langsung maupun lewat infografik dan video infografik (videografi) yang bisa diakses di kanal 'Jelajah'. Kanal 'Periksa Data' adalah salah satu kanal dalam situs tirto.id yang terdiri atas dua format. Format pertama, live fact-check yakni komparasi langsung antara pernyataan

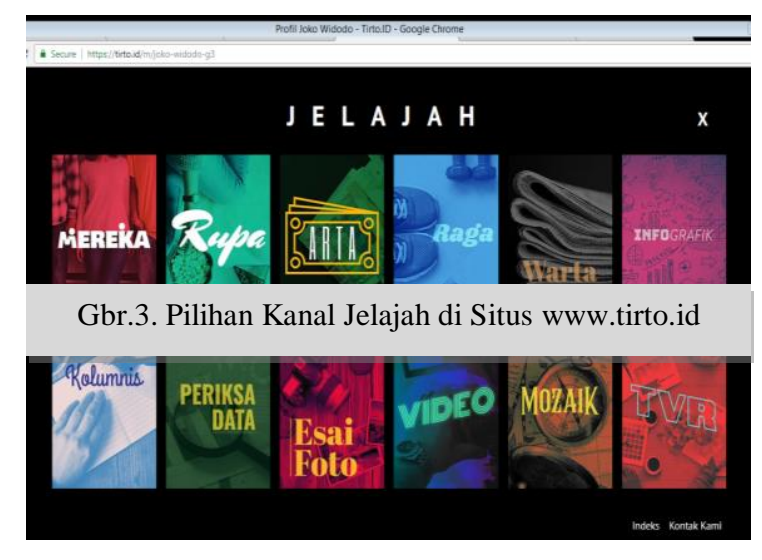
narasumber dengan data resmi. Format kedua, analisis atas isu yang berkembang di masyarakat melalui verifikasi menggunakan sumber data resmi seperti Badan Statistik Negara/Daerah, Pemerintah Pusat/Daerah, Bursa Efek serta laporan perusahaan dan sumber lainnya yang dituliskan dalam bentuk laporan singkat (mild-report). Sumber dari data yang digunakan ditampilkan pada infografik dan link dari data yang digunakan ditautkan pada tulisan dalam bentuk hyperlink ${ }^{23}$.

Adapun media online beritagar.id yang beroperasi sejak 2012, mengusung jurnalisme dengan model pelaporan berbantu komputer atau computer assisted reporting (CAR). Pada November 2013, beritagar.id mengaplikasikan teknologi berbasis Machine Learning (ML) dan Natural Language Processing (NLP), sebuah teknologi komputer yang berhubungan dengan pola pembelajaran kecerdasan buatan dan komputasi linguistik, yakni interaksi antara bahasa

\section{Bęritägarat Car 0}

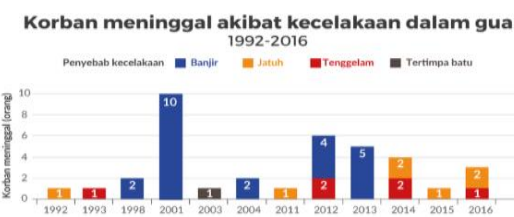

Gbr. 4. Kanal Lokadata di Situs www.beritagar.id

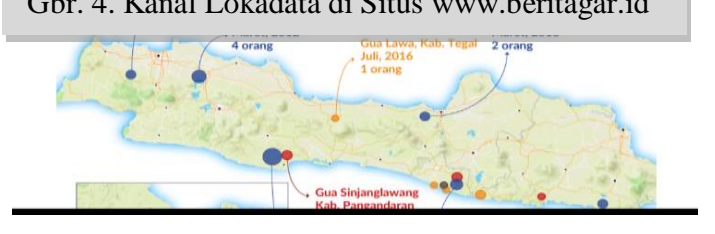

manusia dan komputer. Beritagar.id menyajikan laporan berbasis data di kanal khusus atau situs mini yakni Lokadata. Sebuah kumpulan data yang diambil dari berbagai sumber data publik resmi yang juga bisa diakses oleh khalayak umum. Hal menarik, di 
situs mini Lokadata beritagar.id tampak mencoba menggunakan visual data dalam bentuk peta ${ }^{24}$. Hanya saja, belum ditampilkan secara interaktif. Artinya, khalayak hanya bisa melihat peta statis, beda halnya jika menggunakan aplikasi google map atau aplikasi peta interaktif lainnya.

Media online yang lain seperti independen.id (aktif 2016) dan alinea.id yang baru berdiri 2017 lalu juga berupaya menyajikan laporan berita dengan pendekatan jurnalisme data. Ke dua media ini digawangi oleh profesional jurnalis muda yang sangat menyadari bahwa perkembangan teknologi akan menentukan masa depan situs berita digital dan jurnalisme itu sendiri. Redaksi independen.id menyiapkan kanal khusus yakni kanal 'Data' dengan visual penyajian data yang cukup menarik dengan variasi tampilan data berupa diagram garis, batang dan pie dilengkapi teks berita model laporan mendalam (indepth reporting) ${ }^{25}$. Meski,

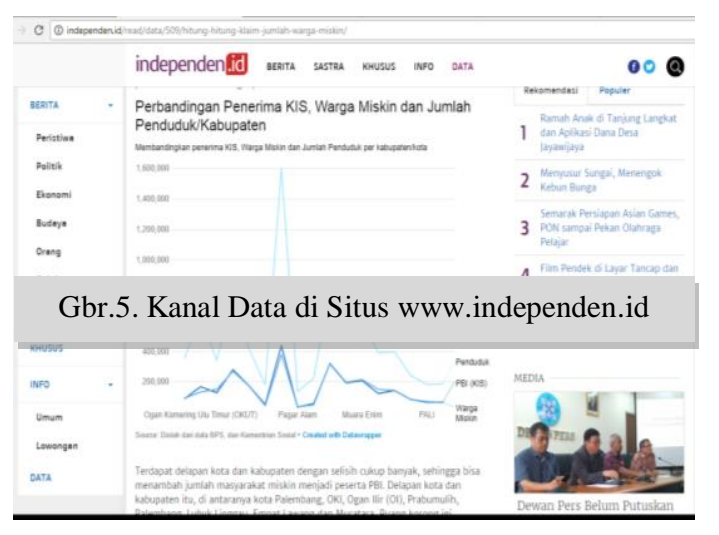
tidak menyediakan kanal infografis atau videografis secara khusus, namun redaksi independen.id mendorong jurnalis melengkapi laporan berita dengan infografis jenis animasi. Hal menarik dari independen.id yakni memberikan ruang khusus bagi topiktopik laporan terkait bidang sastra, sesuatu yang jarang sekali dimunculkan oleh media online sejenis. Meski, laporan atau artikel dalam kanal sastra belum mengadopsi model jurnalisme data. Hal ini, menurut penulis terkait jenis laporan berita yang lebih banyak menggunakan narasi teks, karena menceritakan karya sastra berupa puisi ataupun novel.

Adapun redaksi alinea.id meluncurkan kanal Infografis untuk menyajikan visual data yang dominan menggunakan grafik dan tabel ${ }^{26}$. Alinea.id juga menyajikan data visual yang lebih bervariasi, seperti model diagram pie, heksagonal, grafik, dan sebagainya. Selain itu, alinea.id dengan tagline 'Fakta, Data, Kata' ini juga menyediakan kanal infografis yakni penyajian data dengan konsep visual berupa teks berita yang dilengkapi dengan ilustrasi desain gambar yang menarik. Seperti halnya media online lainnya, infografis yang disajikan rataGbr.6. Kanal Infografis di Situs www.alinea.id 
rata hampir seluruhnya menggunakan jenis infografis statis dan animasi yakni bentuk visual statis, tanpa konsep audio atau animasi yang bisa bergerak (lihat gambar 6.).

Penulis mencermati perkembangan jurnalisme data di

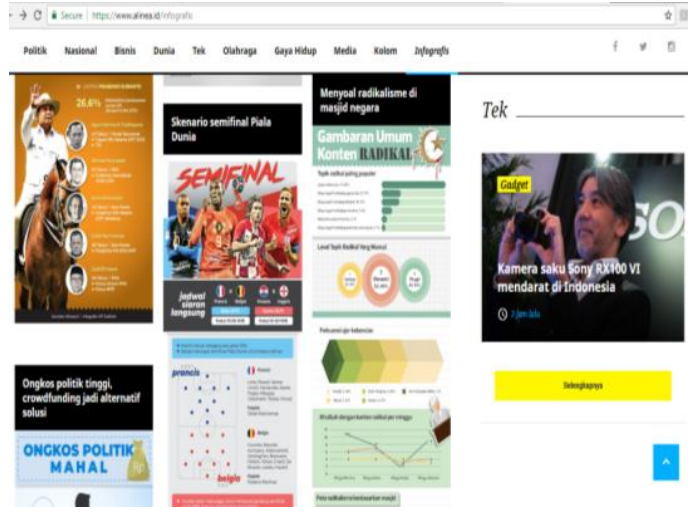
Indonesia masih akan terus mengalami peningkatan baik melalui adopsi maupun inovasi dalam praktik jurnalisme. Merujuk pada angka tingkat penetrasi internet di Indonesia pada Juni 2017 yang mencapai 54.68\% (143,26 juta jiwa) dengan penetrasi pengguna internet didominasi oleh kalangan usia 13-18 tahun (75,50\%) dan usia 19-34 tahun $(74,23 \%)^{27}$, merupakan sebuah potensi pasar yang cukup besar. Jurnalisme data menjadi salah satu pilihan utama pembaca berita dari generasi $\mathrm{Z}$ yang saat ini berada di rentang usia 13-18 tahun. Di era digital ini, khalayak dari generasi Z lebih menyukai sajian informasi dalam bentuk yang lebih variatif dan interaktif seperti penyajian tabel, peta interaktif, infografis dan videografis (multimedia). Sebagai catatan dari hasil pengamatan penulis pada media-media tersebut di atas, terkait penyajian visual data memang belum banyak variasi tampilan data. Visual data dalam bentuk tabel dan grafik tampak lebih dominan, sebagian kecil lainnya menyajikan infografis, peta statis dan videografis. Sejauh ini, penulis belum menemukan tampilan data menggunakan peta interaktif ataupun visual grafik jejaring interaktif. Demikian juga, dalam hal penggunaan infografis belum tampak infografis interaktif dimana khalayak bisa berinteraksi dengan sajian infografiknya.

Hal ini, berbeda dengan media-media online di luar yang kerap menggunakan software atau tools visual data yang lebih bervariasi. Penelitian Young dkk di Canada menunjukkan ada tiga teknik penyajian data visual yang dominan diaplikasikan dalam laporan jurnalisme data yakni peta dinamis, grafik dan video. Adapun fitur-fitur 'elaborate' atau 'extract', 'inspect' dan 'filters' yang tersedia gratis di aplikasi google map menjadi pilihan editor dan jurnalis dalam 
menyajikan data interaktif ${ }^{28}$. Knight juga meneliti sejumlah surat kabar di Inggris yang mengadopsi model jurnalisme data. Hasil penelitiannya menunjukkan jurnalis data the Guardian, the Times, the Daily Telegraph dan the Independent cenderung lebih konsisten menyajikan data dengan tingkat kompleksitas yang tinggi dengan penyajian data visual menggunakan tabel, timeline, peta atau grafik statis, peta dinamis dan infografis. Meski demikian, Knight menyoroti adanya indikasi sejumlah pilihan data dibuat untuk meningkatkan daya tarik visual data namun mengabaikan kejelasan (clarity) data ${ }^{29}$.

Permasalahan ini memang menjadi kendala sekaligus tantangan bagi perkembangan jurnalisme data. Sekali lagi kompetensi jurnalis data sangat dibutuhkan. Terlepas apakah jurnalis memiliki skill dalam pengolahan dan analisis interpretasi serta visualisasi data, seorang jurnalis data tidak bisa meninggalkan konsep dasar jurnalisme, yakni pada fakta, kebenaran dan kejelasan. Dengan demikian, tantangan jurnalisme data bergantung pada kemampuan jurnalis dalam hal pengolahan data-data kuantitatif, kemahiran dalam penyajian visual menggunakan teknologi aplikasi penyajian data atau Application Program Interface (API). Tidak hanya itu, jurnalisme data juga mengandalkan kemampuan menganalisis data dengan mengadopsi metode penelitian yang dikembangkan dalam ilmu-ilmu sosial. Keseluruhan kerja-kerja jurnalisme data tentu saja membutuhkan waktu. Peran organisasi berita sangat penting dalam mengakomodir penerapan jurnalisme data. Penelitian Appelgren dan Nygren menemukan adanya kendala utama penerapan jurnalisme data di Swedia yakni pada metode kerja yang membutuhkan waktu dan kebutuhan training dan pengembangan skill jurnalis data.

Lebih jauh, minimnya akses data terutama data resmi dari pemerintah juga menjadi salah satu tantangan bagi penerapan jurnalisme data, terutama di negaranegara Asia Tenggara ${ }^{30}$. Kalaupun terdapat kemudahan dalam mengakses datadata pemerintah, biasanya masih ada hambatan pada kualitas data. Jurnalis data tetap saja membutuhkan waktu yang lebih untuk melakukan verifikasi berulang kali, membersihkan data (data cleaning) dan melakukan banyak wawancara ke pihak-pihak yang memiliki otoritas dalam menjelaskan data-data yang diperoleh. 
Dengan demikian, dukungan organisasi media sudah tentu dibutuhkan sekali, tidak hanya dalam ruang berita namun juga terkait investasi teknologi dan sumber daya manusia. Organisasi berita sudah saatnya menyediakan ruang seluasnya bagi penerapan dan pengembangan model jurnalisme data. Tidak hanya melalui training dan workshop saja, organisasi berita juga bisa membentuk tim khusus berisi data specialist, programmer, coder ataupun designer yang bisa bekerja bersama dan mendukung aktivitas jurnalis data. Saat ini, jurnalisme data menjadi peluang sekaligus tantangan bagi organisasi berita dalam menginvestasikan sumber daya untuk masa depan media massa dan jurnalisme itu sendiri.

\section{Kesimpulan}

Era digital dengan kekuatan teknologi berbasis internet saat ini mengakibatkan perubahan dalam dunia jurnalistik. Data dan informasi disajikan dan diakses dengan cara dan bentuk yang sama sekali baru. Jurnalisme data hadir sebagai bentuk adaptasi dan inovasi penyajian laporan berita melalui pencarian, pengolahan dan analisis data dalam jumlah yang sangat besar (big data) serta penyajian visual data yang variatif, multimedia dan interaktif. Jurnalisme data di Indonesia meski masih dalam tahap perkembangan awal, namun menunjukkan progres baik kuantitas maupun kualitas pemberitaan yang mengadopsi dan berinovasi pada jurnalisme data. Adapun kendala utama sekaligus tantangan penerapan dan pengembangan jurnalisme data di Indonesia yakni terutama pada kompetensi dan kuantitas jurnalis data yang masih minim, kebutuhan waktu yang lebih lama dalam metode kerja jurnalisme data, dan masih terdapat kesulitan akses data dan informasi di lembaga-lembaga sumber data resmi, serta kecepatan akses jaringan internet di daerah-daerah wilayah Indonesia yang juga masih belum merata. Sebagai implikasi, konsep dan praktik jurnalisme bisa dikaji lebih jauh terkait kendala dan tantangan tersebut di atas, terutama pada media-media lokal. Sehingga jurnalisme dapat terus mengembangkan dirinya sebagai sebuah sistem yang memenuhi kebutuhan informasi bagi khalayak. 


\section{Catatan Akhir}

${ }^{1}$ lihat Alexander Benjamin Howard. The Art and Science of Data-Driven Journalism. https://towcenter.org/the-art-and-science-of-data-driven-journalism/ (28 Juli 2018). h.4.

${ }^{2}$ lihat Simon Rogers, dkk. Data Journalism in 2017: The Current State and Challenges Facing The Field Today. Diperoleh dari : https://newslab.withgoogle.com/assets/docs/data-journalism-in-2017.pdf. (diakses 20 Juli 2018). h.10

${ }^{3}$ lihat Thomas Schulze."Data Journalism, Millennials \& Social Network: What does data journalism mean for journalist? And how it can affect the Millennials." Thesis. Porto: Journalism, University Fernando Pessoa. 2015. Diperoleh dari : http://www.rcaap.pt/detail.jsp?id=oai:bdigital.ufp.pt:10284/5039 (diakses 14 Juli 2018). h.7. Hal yang sama juga disebutkan di beberapa jurnal penelitian seperti Johannah Fulda dan Stefanie Neubert. "What Obstacles that Data Driven-Journalism have to overcome". h.3

${ }^{4}$ lihat Julian Ausserhoufer, dkk."The Datafication of Data Journalism Scholarship: Focal Points, Methods, and Research Propositions for The Investigation of Data Intensive-newswork". Journalism. 1-24 (4 April 2017). http://journals.sagepub.com/doi/10.1177/1464884917700667 (diakses 21 Juli 2018). h.11-17

${ }^{5}$ lihat Mark Deuze dan Tamara Witschge.'Beyond Journalism:Theorizing the Transformation of Journalism". Journalism. 1-17 (07 Februari 2017). http://journals.sagepub.com/doi/full/10.1177/1464884916688550. (diakses 01 Agustus 2018). h.12

${ }^{6}$ Shan Suthaharan. "Big Data Classification: Problems and Challenges in Network Intrusion Prediction with Machine Learning." Sigmetrics Perform. Eval. Rev. Vol.41-4. (Maret 2014). https://dl.acm.org/citation.cfm?doid=2627534.2627557. (diakses pada 01 Agustus 2018). h.70

${ }^{7}$ Syamsuddin Aziz."Mediatisasi Komunikasi di era Post Truth".(Makalah yang dipresentasikan pada seminar International Conference Communication, UIN Alauddin Makassar, 04 Juli 2018). h.4

${ }^{8}$ lihat Seth C. Lewis dan Oscar Westlund. "Big Data and Journalism:Epistemology, Expertise, Economic, and Ethics".Digital Journalism. Vol.3-3 (27 November 2014). https://www.tandfonline.com/doi/abs/10.1080/21670811.2014.976418?journalCo de $=$ rdij20. (diakses 02 Agustus 2018). h.4-6. Hal ini juga dibahas oleh Alexander Benjamin Howard. The Art and Science of Data-Driven Journalism.

https://towcenter.org/the-art-and-science-of-data-driven-journalism/(28 Juli 2018). h.14-15.

${ }^{10}$ Simon Rogers, dkk. Data Journalism in 2017:The Current State and Challenges Facing The Field Today. Diperoleh dari : https://newslab.withgoogle.com/assets/docs/data-journalism-in-2017.pdf. (diakses 20 Juli 2018).h.4 
${ }^{9}$ buka link https://lasvegassun.com/hospital-care/ (diakses 16 Juli 2018). Dibahas juga oleh Yunanto Wiji Utomo. "Statistika, Komputer, dan Jurnalisme Masa Depan”. kompas.com,15 Juni 2016.

https://sains.kompas.com/read/2015/06/15/13021221/Statistika.Komputer.dan.Jur nalisme.Masa.Depan. (diakses 16 Juli 2018)

${ }^{11}$ lihat Alexander Benjamin Howard. The Art and Science of Data-Driven Journalism. https://towcenter.org/the-art-and-science-of-data-driven-journalism/ (28 Juli 2018). h.7.

${ }^{12}$ lihat Eddy Borges-Rey."Towards an Epistemology of Data Journalism in The Devolved Nations of The United Kingdom: Changes and Continuities in Materiality, Performativity and Reflexivity" Journalism.1-18 (1 Februari 2017). http://journals.sagepub.com/doi/abs/10.1177/1464884917693864 (diakses 25 Juli 2018). h.3-4. Lihat juga Jan Lauren Boyles dan Eric Meyer. "Newsroom Accommodate Database Newswork". Newspaper Research Journal. Vol. 38 (4). (14 November 2017).

http://journals.sagepub.com/doi/abs/10.1177/0739532917739870. (diakses $31 \mathrm{Juli}$ 2018). h.436

${ }^{13}$ Megan Knight.'Data Journalism in the UK: a Preliminary Analysis of Form and Content. Journal of Media Practice. Vol. 16, No. 1. ( Maret 2018) https://www.researchgate.net/publication/276833612_Data_journalism_in_the_U K_A_preliminary_analysis_of_form_and_contentDOI :

10.1080/14682753.2015.1015801. (diakses 24 Juli 2018). h.57-59

${ }^{14}$ Paul Bradshaw. The Inverted Pyramid of Data Journalism. Blog Jurnalisme Online. (07 Juli 2011).

http://onlinejournalismblog.com/2011/07/07/the-inverted-pyramid-of-data-journal ism/. (diakses 22 Juli 2018).

${ }^{15}$ lihat Thomas Schulze. “Data Journalism, Millennials \& Social Network:

What does data journalism mean for journalist? And how it can affect the Millennials." Thesis. Porto: Journalism, University Fernando Pessoa. 2015. Diperoleh dari : http://www.rcaap.pt/detail.jsp?id=oai:bdigital.ufp.pt:10284/5039 (diakses 14 Juli 2018). h.10

${ }^{16}$ lihat Sylvain Parasie dan Eric Dagiral.’Data-driven journalism and the public good: 'Computer-assistedreporters' and 'programmer-journalists' in Chicago. New Media \& Society 15(6).(18 November 2012). http://journals.sagepub.com/doi/abs/10.1177/1461444812463345. (diakses $26 \mathrm{Juli}$ 2018). h. 853-871

${ }^{17}$ lihat Philip Meyer.’The New Precision Journalism". Chapter 1. Journalism and Scientific Tradition. Tersedia di : https://www.unc.edu/ pmeyer/book/Chapter1.htm. (diakses 08 Agustus 2018).

${ }^{18}$ baca lebih lanjut Simon Rogers. "Data Journalism at The Guardian: What is it and how we do it". (artikel). Kanal Datablog, theguardian.com. (28 Juli 2011). https://www.theguardian.com/news/datablog/2011/jul/28/data-journalism. (diakses 02 Agustus 2018)

${ }^{19}$ baca lebih lanjut "Jejak Korupsi Global dari Panama". (Laporan Investigasi). Tempo Online (05 April 2016). https://investigasi.tempo.co/panama/. (diakses 27 Juli 2018) 
${ }^{20}$ buka link https://vik.kompas.com/index.php/all (diakses 30 Juli 2018)

${ }^{21}$ lihat Muhammad Badri. Inovasi Jurnalisme Data Media Online di Indonesia. Diperoleh dari : http://id.spsindonesia.org/file/_/arh2fqc0c4k4314. (diakses pada 02 Agustus 2018).h.10

${ }^{22}$ buka link https://databoks.katadata.co.id/datapublish/2018/07/26/10negara-dengan-cadangan-terbukti-minyak-terbesar. (diakses 27 Juli 2018)

${ }^{23}$ buka link https://tirto.id/q/periksa-data-gqo. (diakses pada 31 Juli 2018)

${ }^{24}$ baca lebih lanjut "Banjir Jadi Ancaman Utama Kecelakaan dalam Gua". (Liputan Berita). Kanal Lokadata, beritagar.id (19 Juli 2018). https://beritagar.id/artikel/berita/banjir-jadi-ancaman-utama-kecelakaan-dalamgua. (diakses 27 Juli 2018)

${ }^{25}$ buka link https://independen.id/channel/data. (diakses 31 Juli 2018)

${ }^{26}$ buka link https://www.alinea.id/infografis. (diakses 31 Juli 2018)

${ }^{27}$ bisa diunduh di https://apjii.or.id/survei2017/kirimlink. (diakses pada 08 Agustus 2018)

${ }^{28}$ lihat Mary Lynn Young, dkk."What Makes Great for Data Journalism : a content analysis of data journalism awards finalists 2012-2015". Journalism Practice. Vol.12-1. (09 Februari 2017).

https://www.tandfonline.com/doi/abs/10.1080/17512786.2016.1270171. (diakses 05 Agustus 2018). h.115-135

${ }^{29}$ lihat Megan Knight."Data Journalism in the UK: a Preliminary Analysis of Form and Content. Journal of Media Practice. Vol. 16, No. 1. ( Maret 2018) https://www.researchgate.net/publication/276833612_Data_journalism_in_the_U K_A_preliminary_analysis_of_form_and_contentDOI 10.1080/14682753.2015.1015801. (diakses 24 Juli 2018). h.67-69

${ }^{30}$ baca lebih jauh, Siran Liang. "One Man Mission to Spread Data Journalism Across South East Asia". Artikel, Situs Global Investigative Journalism Network. (30 Juli 2018). https://gijn.org/2018/07/30/one-mansmission-to-spread-data-journalism-across-southeast-asia/. Diakses pada 04 Agustus 2018.

\section{Daftar Pustaka}

Appelgren, E. \& Nygren, G. "Data Journalism in Sweden". Digital Journalism, Vol.2:3 (September 2014) https://www.researchgate.net/publication/271682054_Data_Journalism_in _Sweden. DOI: 10.1080/21670811.2014.884344 (diakses 18 Juli 2018)

Ausserhoufer, J. dkk.’'The Datafication of Data Journalism Scholarship: Focal Points, Methods, and Research Propositions for The Investigation of Data Intensive-Newswork". Journalism. 1-24 (4 April 2017). http://journals.sagepub.com/doi/10.1177/1464884917700667 (diakses 21 Juli 2018)

Badri, M. Inovasi Jurnalisme Data Media Online di Indonesia. Diperoleh dari : http://id.spsindonesia.org/file/_/arh2fqc0c4k4314. (diakses pada 02 Agustus 2018)

"Banjir Jadi Ancaman Utama Kecelakaan dalam Gua". (Liputan Berita). Kanal 
Lokadata, Beritagar Online (19 Juli 2018). https://beritagar.id/artikel/berita/banjir-jadi-ancaman-utama-kecelakaandalam-gua. (diakses 27 Juli 2018)

Biagi, Shirley. Media/Impact : An Introduction to Mass Media. Cengage Learning Asia : Singapore. 2010

Borges-Rey,E."Towards an Epistemology of Data Journalism in The Devolved Nations of The United Kingdom: Changes and Continuities in Materiality, Performativity and Reflexivity" Journalism.1-18 (1 Februari 2017). http://journals.sagepub.com/doi/abs/10.1177/1464884917693864 (diakses 25 Juli 2018)

Boyles, J.L. dan Eric Meyer. "Newsroom Accommodate Database Newswork". Newspaper Research Journal. Vol. 38 (4). (14 November 2017). http://journals.sagepub.com/doi/abs/10.1177/0739532917739870. (diakses 31 Juli 2018)

Bradshaw, Paul. "The Inverted Pyramid of Data Journalism". Blog jurnalisme Online Paul Bradshaw. http://onlinejournalismblog.com/2011/07/07/theinverted-pyramid-of-data-journalism/. (diakses 22 Juli 2018).

"Do No Harm : Hospital Care in Las Vegas, A breakthrough in medical transparency". News and Document. Las Vegas Sun.com. 2010. https://lasvegassun.com/hospital-care/ (diakses 16 Juli 2018)

Gray, J. dkk The Data Journalism Handbook. https://www.researchgate.net/publication/281376035_The_Data_Journalis m_Handbook (01 Agustus 2018)

Hammond, Philip. "From Computer Assisted to Data Driven: Journalism and Big Data". Journalism, 1-17 (15 Desember 2015) http://journals.sagepub.com/doi/abs/10.1177/1464884915620205?.journalC ode=joua. (diakses 07 Juli 2018)

"Hitung-Hitung Klaim Jumlah Warga Miskin". (Liputan Berita). Kanal Data, Independen Online (06 Oktober 2017). http://independen.id/read/data/509/hitung-hitung-klaim-jumlah-wargamiskin/. (diakses 27 Juli 2018)

Howard, Alexander B. The Art and Science of Data-Driven Journalism. https://towcenter.org/the-art-and-science-of-data-driven-journalism/ Juli 2018)

https://vik.kompas.com/index.php/all. (diakses 30 Juli 2018)

https://tirto.id/q/periksa-data-gqo. (diakses 31 Juli 2018)

"Jejak Korupsi Global dari Panama". (Laporan Investigasi). Tempo Online (05 April 2016). https://investigasi.tempo.co/panama/. (diakses 27 Juli 2018)

Kovach, Bill dan Tom Rosenstiel. Sembilan Elemen Jurnalisme. Jakarta : Pantau 2012

Knight, Megan. "Data Journalism in the UK: a Preliminary Analysis of Form and Content". Journal of Media Practice. Vol. 16, No. 1 (Maret 2015) https://www.researchgate.net/publication/276833612_Data_journalism_in _the_UK_A_preliminary_analysis_of_form_and_content. DOI : $10.1080 / 14682753.2015 .1015801$ (diakses 28 Juli 2018)

Lewis, Seth.C dan Oscar Westlund. "Big Data and Journalism:Epistemology, 
Expertise, Economic, and Ethics".Digital Journalism. Vol.3-3 (27

November 2014).

https://www.tandfonline.com/doi/abs/10.1080/21670811.2014.976418?jou rnalCode=rdij20. (diakses 02 Agustus 2018)

Liang, Siran. "One Man Mission to Spread Data Journalism Across South East Asia”. Artikel, Situs Global Investigative Journalism Network. (30 Juli 2018). $\quad$ https://gijn.org/2018/07/30/one-mans-mission-to-spread-datajournalism-across-southeast-asia/. Diakses pada 04 Agustus 2018.

Maeyer, Juliette. D, dkk. "Waiting for Data Jounalism: A Qualitative Assesment of The Anecdotal Take-up of Data Journalism in French-speaking Belgium". Digital Journalism. Vol.3-3 (27 November 2014). https://www.tandfonline.com/doi/abs/10.1080/21670811.2014.976415. (diakses 30 Juli 2018)

Meyer, Philip."The New Precision Journalism”. Chapter 1. Journalism and Scientific Tradition. Tersedia di : https://www.unc.edu/ pmeyer/book/Chapter1.htm. (diakses 08 Agustus 2018)

Parasie, Sylvain dan Eric Dagiral.'Data-driven journalism and the public good: 'Computer-assistedreporters' and 'programmer-journalists' in Chicago. New Media \& Society 15-6. (18 November 2012) http://journals.sagepub.com/doi/abs/10.1177/1461444812463345. (diakses 26 Juli 2018)

Rogers, Simon, dkk. Data Journalism in 2017:The Current State and Challenges Facing The Field Today. Diperoleh dari : https://newslab.withgoogle.com/assets/docs/data-journalism-in-2017.pdf. (diakses 20 Juli 2018)

Rogers, Simon. "Data Journalism at The Guardian: What is it and how we do it". (artikel). Kanal Datablog, theguardian.com. (28 Juli 2011) https://www.theguardian.com/news/datablog/2011/jul/28/data-journalism. (diakses 02 Agustus 2018)

"10 Negara dengan Cadangan Terbukti Minyak Terbesar". (Liputan Berita). Kanal Databoks, Katadata Online (26 Juli 2018).

https://databoks.katadata.co.id/datapublish/2018/07/26/10-negara-dengancadangan-terbukti-minyak-terbesar. (diakses 27 Juli 2018)

Schulze, Thomas. "Data Journalism, Millennials \& Social Network: What does data journalism mean for journalist? And how it can affect the Millennials.” Thesis. Porto: Journalism, University Fernando Pessoa. 2015. Diperoleh dari : http://www.rcaap.pt/detail.jsp?id=oai:bdigital.ufp.pt:10284/5039 (diakses 14 Juli 2018)

Solop, Frederick .I. dan Nancy A. Wonders. "Data Journalism Versus Traditional Journalism in Election Reporting:An Analysis of Competing Narratives in the 2012 Presidential Election”. Electronic News. 1-21. (04 Juli 2016). http://journals.sagepub.com/doi/abs/10.1177/1931243116656717 (diakses 10 Juli 2018)

Stampfel, Nora.S. Data Journalism : Data with a story to tell. Diperoleh 
dari https://www.goethe.de/en/kul/med/20744960.html (diakses pada 15 Juli 2018)

Suthaharan, Shan. "Big Data Classification: Problems and Challenges in Network Intrusion Prediction with Machine Learning." Sigmetrics Perform. Eval. Rev. Vol.41 (4). (Maret 2014) https://dl.acm.org/citation.cfm?doid=2627534.2627557. (diakses pada 01 Agustus 2018)

Utama, E. "A seat Reserved for Data Journalism in Online-Savvy Indonesia". Dalam Winkelmann.S. Data Journalism In Asia. Konrad Adenauer Stiftung. $\quad$ Singapore. $2013 . \quad$ Tersedia dari http://www.kas.de/wf/doc/kas_35547-1522-2-30.pdf?130930105436. (diakses 01 Agustus 2018)

Utomo, Yunanto W. "Statistika, Komputer, dan Jurnalisme Masa Depan”. kompas.com, 15 Juni 2016. https://sains.kompas.com/read/2015/06/15/13021221/Statistika.Komputer. dan.Jurnalisme.Masa.Depan. (diakses 16 Juli 2018)

Young, Mary Lynn, dkk."What Makes Great for Data Journalism : a content analysis of data journalism awards finalists 2012-2015". Journalism Practice. Vol.12-1. (09 Februari 2017). https://www.tandfonline.com/doi/abs/10.1080/17512786.2016.1270171. (diakses 05 Agustus 2018) 